\title{
Researching Malformations in Frogs of the Pelophylax esculentus Complex (Amphibia: Anura) in the Natural Populations of the Trakhtemyriv Peninsula (Ukraine)
}

\section{O.D. Nekrasova ${ }^{1}$ and V.V. Kuibida²}

${ }^{1}$ I.I. Schmalhausen Institute of Zoology of National Academy of Sciences of Ukraine, st. Bogdana Khmelnitskogo, 15, Kyiv, 01030, Ukraine

${ }^{2}$ Pereyaslav-Khmelnytsky Hryhoriy Skovoroda State Pedagogical University (SHEE), Sukhomlinsky Str., 30, Pereyaslav-Khmelnitsky, Kyiv region, 08401, Ukraine

\section{Abstract}

As a result of research held during student practicals between 2012 and 2016 and a study of the population of the Pelophylax esculentuscomplex, we have found up to $13.3 \%$ of samples from the species Pelophylax ridibundus have abnormalities.

Corresponding Author: O.D. Nekrasova oneks22@gmai.com

Received: 23 January 2018 Accepted: 20 April 2018 Published: 3 May 2018

Publishing services provided by Knowledge E

(c) O.D. Nekrasova and V.V. Kuibida. This article is distributed under the terms of the Commons Attribution License, which permits unrestricted use and redistribution provided that the original author and source are credited.

Selection and Peer-review under the responsibility of the Amphibian and Reptiles Anomalies and Pathology Conference Committee.

\section{S OPEN ACCESS}

\section{Introduction}

The decline in the population of amphibians and the appearance of a huge number of species with various abnormal features over the last two decades has aroused huge concern among scientists. The literature describes amphibian anomalies in Eastern Ukraine [2], Western Ukraine [1, 3, 10], Southern Ukraine [5], and in Ukraine generally [4]. In the middle Dnipro region, we previously registered malformations in limbs, heads (craniofacial), spines, skin, etc. [6]. According to the literature, anomalies are rarer in natural populations than in populations in an anthropogenic environment (Vershinin, 1997; Nekrasova, 2002; Borkin et al., 2012), and therefore there is huge interest in the natural biotopes of the Trakhtemyriv Peninsula. The peninsula is situated in the middle of the Dnieper River and is surrounded on three sides by the waters of the Kaniv water storage plant. In the mid-1970s, the construction and opening of the water storage plant had a significant influence on the flora and fauna of this region. The regional landscape park "Trakhtemyriv" is located on the territory of the peninsula. 


\section{Methods}

We sampled abnormal anurans belonging to Pelophylax esculentuscomplex from the Trakhtemyriv Peninsula (Cherkasy region) near the village of Buchak ( $49^{\circ} 51^{\prime} 53^{\prime \prime} \mathrm{N}$, $31^{\circ} 26^{\prime} 21^{\prime \prime} E$ ). During the field work, material was collected by the student-biologists of Pereiaslav-Khmelnytskyi State Pedagogic University named after Hryhorii Skovoroda in 2012 ( 57 species collected in July) and in 2013 (45 species collected in July). The total amount of the material collected and researched was 102 frog species (ad \& sad). In 2014 - 2016, only the number of amphibians was studied. The frogs were examined according to standard methods during their life cycles. They were classified in terms of their morphological traits [6]. The anomalies were studied according to the classification system we developed earlier ([7]; Fig.1).

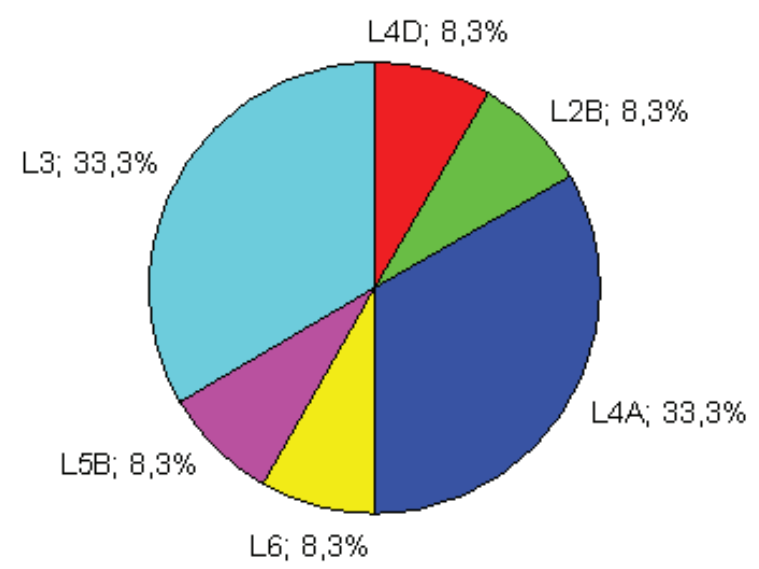

Figure 1: The proportion of the occurrence of various types of abnormalities in lake frogs on the Trakhtemyriv Peninsula (2012-2013, subscriptions in the text).

\section{Results}

As a result of the research, it was found that all members of the green frog Pelophylax esculentuscomplex can be found in the investigated territory - parents of the marsh frog Pelophylax ridibundus (Pallas, 1771) (in $2012-71 \%$; in 2013-93\%); the pool frog Pelophylax lessonae (Camerano, 1882) (in 2012-5.2\%; in 2013-4.4\%); and their hybrid Pelophylax kl. esculentus (in $2012-23.8 \%$; in $2013-2.6 \%$ ). Therefore, it was indicated that in mixed population systems (LER type) there were fewer hybrids and pool frogs. The total number of frogs was two times lower. Anomalies were found only in $P$. 
ridibundus:in 2012, they were found in 5.2\% of the specimens, and in 2013 in $13.3 \%$ (3 frogs each had 2 anomalies).

Limb Malformations (Fig.1, 2).

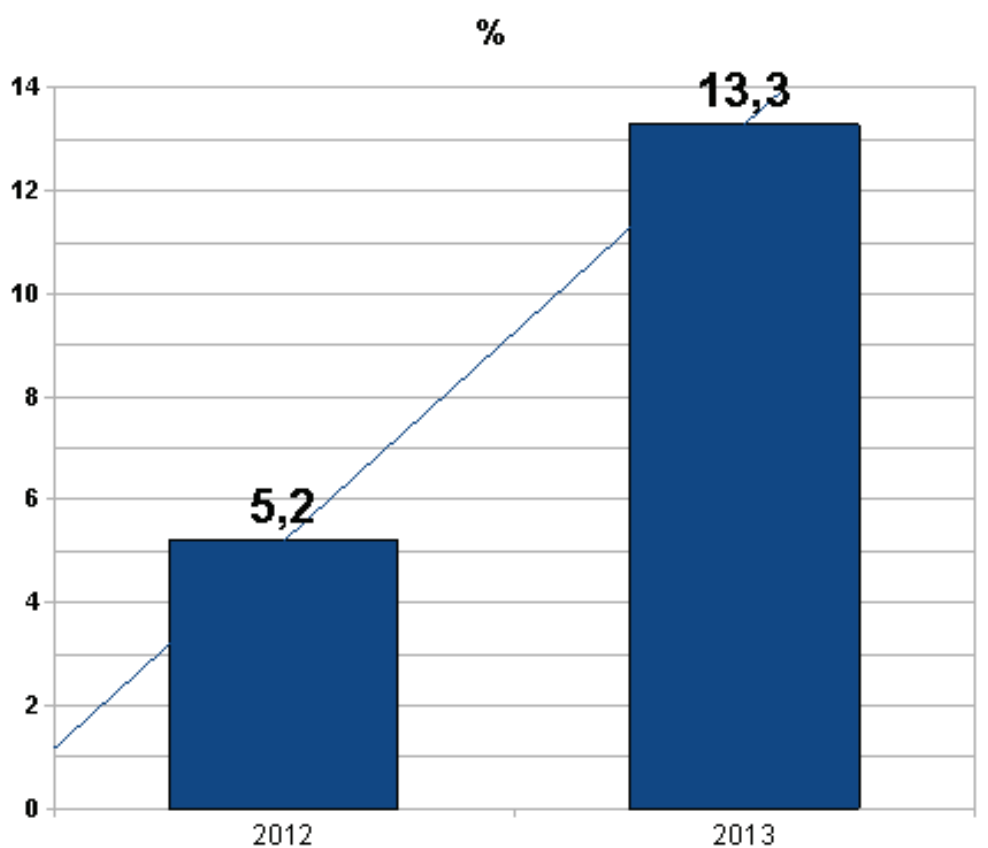

Figure 2: The proportion of frogs with abnormalities on the Trakhtemyriv Peninsula.

Phocomelia (L2B) - absence of the proximal portion of a limb, found in $8.3 \%(f, 2013)$.

Rotation $(\mathrm{L} 3 \mathrm{C})$ - rotation different parts of the limbs, often found in $33.4 \%(\mathrm{~m}, \mathrm{f}, 2012-$ 2013).

Ectrodactyly (L4A) - missing part of limb or digits. Found in $33.4 \%(\mathrm{~m}, \mathrm{f}, 2013)$.

Mixed patterns (L4D) - Brachydactyly (short toes or missing phalanges) and Ectrodactyly, found in $8.3 \%$ (f, 2012).

Polyphalangy (L5B) - extra bones in a digit, found in 8.3\% (2013).

Polymelia (L6) - with one extra hind limb, found in 8.3\% (f, 2013; Fig. 3). A similar number of cases of polymelia were found in lake frogs ( $P$. ridibundus) from the park "Kin-Grust" in Kyiv. In 2001, up $42 \%$ of specimens had additional limbs (up to 7 ; Nekrasova et al., 2007).

The artificial lake Buchak emerged in place of the lower pit of the incomplete Kaniv Pumped Storage Plant. The construction of the plant started in 1984 and was suspended after the Chornobyl NPP accident. In 1992, all construction works were completely stopped for economic reasons. During the construction, part of the village of Buchak was partially relocated and demolished, with the oak forest being uprooted and the existing ecosystem disrupted. It is worth mentioning that some oaks 1.5 meters in 




Figure 3: Picture of polymelia (L6) - P. ridibunduswith one extra hind limb.

diameter were preserved in certain areas ( $400 \mathrm{~m}$ from the fish farm). Lake Buchak is a drainage lake filled by waters from springs. It was here that we found for the first time a new kind of reptilian - Natrix tessellato - for the Cherkasy region [6]. Recently, tourist activities have had a strong influence on the lake. The number of amphibians is in gradually decline.

\section{Conclusion}

As a result of this work, we came to the conclusion that hybrids and pool frogs were the most sensitive to the changing conditions, as their populations decline with each year. Meanwhile, the number of marsh frogs with anomalies increased to $13.3 \%$, and the range of the anomalies has increased to 6 variants. Possible explanations for the emergence of anomalies in natural waters could be parasitic invasions, natural background factors (the general deterioration of water conditions in the Dnipro River and radioactive background from the gamma radiation in granite outlets) and significant recreational activities during amphibian breeding and development. In the near future, we plan to study this phenomenon more precisely. 


\section{References}

[1] Fedoniuk OV: Amphibians and reptiles, their morphological anomalies and nonstandard phenomena as consequence of anthropological influences upon forestry ecosystems in Lviv region. In: Interdepartmental Sci.-Tech. Misc.: Forest, paper and wood industry. 2008; 32: 355-360 [in Ukrainian].

[2] Flyaks NL, Borkin LJ: Morphological abnormalities and heavy metal concentrations in anurans of contaminated areas, eastern Ukraine. Applied Herpetology, 2004; 1: 229-264 [in Russian].

[3] Kurtyak FF: Anomalies of the development of faintnesses in unisex hybrid populations Pelophylax klepton esculento (Linnaeus, 1758) (Amphibia, Anura, Ranidae) in the Transcarpathian Lowlands. In: Scientific Bulletin of the Uzhgorod University. 2010; Biology; 28: 132-134 [in Ukrainian].

[4] Marushchak OY, Muravynets AA: Morphological abnormalities in natural populations of anurans (Amphibia, Anura) in Ukraine. In: Proceedings of the Ukranian Herpetological Society. 4. Kyiv, 2013: 87-94 [in Ukrainian].

[5] Mikitinez Gl: Geographical occurrence in populations of morphological abnormalities Anura of steppe zone Ukraine. In: Proceedings of the International Conference "Anomalies and Pathologies of Amphibians and Reptiles: Methodology, Evolutionary Impact, Possibilities for Estimation of Environmental Health" (23-26 September 2013, Yekaterinburg, Russia), 2014: 136-144 [in Russian].

[6] Nekrasova OD: Population structure and hybridization of green frogs of the Rana esculento complex from urban territories of the Middle Dnieper basin. - Manuscript. Candidate thesis. Speciality: 03.00.02. - Zoology. - Schmalhausen Institute of Zoology, National Academy of Sciences of Ukraine, Kyiv, 2002 [in Ukrainian].

[7] Nekrasova OD: Classification of Amphibians Anomalies. In: Proceedings of the Ukranian Herpetological Society. 1; Kyiv, 2008: 55-58 [in Russian].

[8] Nekrasova OD, Gavris GG, Kuybida VV: Changes in the nothern border of the home range of the dice snake, Natrix tessellata (Reptilia, Colubridae) in the Dnipro basin (Ukraine). Vestnik zoologii; 2013; 47(5): 67-71.

[9] Nekrasova OD, Mezhzherin SV, Morozov-Leonov SYu, Sytnik YuM: A cases of mass polymelia in the lake frog (Rana ridibunda Pall., 1771) from Kyiv. Scientific Bulletin of the Uzhgorod University, (Ser. Biol.), 2007: 92-95 [in Russian].

[10] Smirnov NA: About the morphological abnormalities in newts of the genus Lissotriton (Salamandridae, Caudata) in Western Ukraine. In: Proceedings of the International Conference "Anomalies and Pathologies of Amphibians and Reptiles: 
Methodology, Evolutionary Impact, Possibilities for Estimation of Environmental Health" (23-26 September 2013, Yekaterinburg, Russia), 2014: 165-171 [in Russian].

[11] Vershinin VL: Ecological features of amphibian populations in urbanized areas. Manuscript. Doctoral thesis. Yekaterinburg, 1997 [in Russian]. 